\title{
Botanical Characterization of Brazilian Honeys by Nuclear Magnetic Resonance Spectroscopy and Chemometrics
}

\author{
Salgueiro, F. B.; Lira, A. L.; Rumjanek, V. M.; Castro, R. N.* \\ Rev. Virtual Quim., 2016, 8 (1), 277-287. Data de publicação na Web: 8 de janeiro de 2016 \\ http://rvq.sbq.org.br
}

\section{Caracterização Botânica de Méis Brasileiros por Espectroscopia de Ressonância Magnética Nuclear e Quimiometria}

Resumo: O mel é um dos alimentos mais estudados devido às suas propriedades nutricionais e medicinais. RMN pode ser usado na análise de alimento para discriminação da origem e identificação de biomarcadores utilizando uma abordagem metabolômica. Neste estudo, nós apresentamos um exemplo desta estratégia para tipificar amostras de mel de diferentes origens botânicas. Onde 53 extratos de méis ricos em polifenóis foram preparados utilizando resina de adsorção XAD-4 e os seus espectros de $\mathrm{RMN}$ de ${ }^{1} \mathrm{H}$ associados à análise multivariada foram utilizados para detectar possíveis biomarcadores de origem floral. A análise de componentes principais foi aplicada com sucesso na discriminação entre amostras de mel de eucalipto, laranjeira e cambará.

Palavras-chave: Classificação de mel; RMN; Análise por Componentes Principais (PCA).

\section{Abstract}

Honey is one of the most studied foods due to its nutritional and medicinal properties. NMR can be used in food analysis for origin discrimination and biomarker identification using a metabolomic approach. In this study, we present an example of this strategy to discriminate honey samples from different botanical origins. The NMR spectra coupled with multivariate statistical analysis of 53 polyphenol-rich extracts prepared using adsorption resin XAD-4 of selected honey samples were analyzed to detect possible biomarkers of their floral origin. Principal component analysis was successfully applied for the discrimination among eucalyptus, orange and cambara honey samples.

Keywords: Honey classification; NMR; principal component analysis (PCA).

* Universidade Federal Rural do Rio de Janeiro, Departamento de Química, Instituto de Ciências Exatas, CEP 23897-000, Seropédica-RJ, Brasil.

Mnora@ufrij.br DOI: $\underline{10.5935 / 1984-6835.20160018}$ 


\title{
Botanical Characterization of Brazilian Honeys by Nuclear Magnetic Resonance Spectroscopy and Chemometrics
}

\author{
Fernanda B. Salgueiro, Aline F. Lira, Victor M. Rumjanek, Rosane N. \\ Castro*
}

Universidade Federal Rural do Rio de Janeiro, Departamento de Química, Instituto de Ciências Exatas, CEP 23897-000, Seropédica-RJ, Brasil.

*nora@ufrri.br

Recebido em 3 de janeiro de 2016. Aceito para publicação em 3 de janeiro de 2016

\section{Introduction}

\section{Experimental}

\subsection{Reagents}

2.2. Sample Collection

2.3. Sample Preparation

2.4. ${ }^{1} \mathrm{H}$ NMR Spectroscopy

2.5. Sample Fortification

2.6. Multivariate Analysis

2.7. HPLC analysis of the phenolic profile of honey

\section{Results and discussion}

\section{Conclusions}

\section{Introduction}

Honey is a complex mixture of around 200 compounds, but carbohydrates make up most of the content. Minor substances such as enzymes, aminoacids, minerals, organic acids, vitamins, waxes and pollen grains can also be found. ${ }^{1-3}$

Thus, honey is basically a supersaturated fructose and glucose solution, with about $17 \%$ of water in its final composition. That is due to the action of water evaporation promoted by the bees, which keep fanning the nectar to expose it to air and therefore eliminate the excess humidity. Also, they use their proboscis (long hairy tongue) to absorb part of the water and insert some enzymes. Besides being a homeostasis process, water removal increases the concentration of fructose and glucose, making honey a more stable food and therefore less susceptible to microbiological contamination. ${ }^{4}$

Previous researches showed that honey has functional properties in humans that may promote health improvement, but which greatly depend on the floral origin. ${ }^{5}$ The control of commercial honeys, therefore, requires the correct determination of the 
floral origins as part of the overall evaluation of the quality of honey.

Honey floral origin is generally determined by pollen analysis (melissopalinology), as the type of pollen may reflect the nectar source. However, melissopalinology has some limitations: specialized professionals with a great knowledge of morphology are necessary to ensure trustworthy results. Furthermore, some pollen grains, such as those from Citrus species and members of the Lamiaceae family, are sub-represented in the pollinic spectra of honey, while other species such as Eucalyptus, Castanea and Myosotis are over-represented. Thus, a minimum of $10 \%$ of Citrus sp. pollen content is enough to consider the honey as unifloral, while a minimum of $70 \%$ of Eucalyptus pollen is necessary to classify it as unifloral. ${ }^{6}$ The difficulties on the determination of pollen content in some types of honey may afford wrong results if not confirmed by other techniques such as the determination of floral markers by high resolution liquid chromatography or gas chromatography. ${ }^{7}$ Many other studies were carried out to develop other methodologies and other analytical procedures, generally associated to chemometric analysis to help evaluate the honey's floral origin. ${ }^{8}$

Among many other analytical methods used for food characterization, Nuclear Magnetic Resonance (NMR) has been applied to food with the aim of characterization as well as detection of adulteration and has earned general acceptance as an efficient method $^{9,10}$ due to its non-destructive feature, along with high reproducibility and sensitivity. This new screening method using ${ }^{1} \mathrm{H} \quad \mathrm{NMR}$ has been combined with chemometrics. The approach consists in applying principal component analysis (PCA) to reduce the data dimensionality.

Lately, an increasing interest in the development of analytical methods that may complement pollen analysis on the determination of honey floral origin has been observed in the literature. The analysis of phenolic compounds by high pressure liquid chromatography (HPLC) has been shown to be an efficient method in the study of floral and geographic origins of honey. ${ }^{11-14}$ In the early years, researchers have employed aminoacid analysis ${ }^{15}$, volatile compounds, ${ }^{16,17}$ phenolic compounds, ${ }^{11}$ aromatic acids and their esters ${ }^{18}$ and carotenoids ${ }^{19}$ for the determination of floral and geographic origins of European honeys, by using gas chromatography coupled to mass spectrometry.

\section{Experimental}

\subsection{Reagents}

Methanol used for the analyses was spectrophotometric grade (VETEC), and water was previously passed through a Millipore filter (Millipore Direct-Q UV with pump). Reference compounds benzoic acid, $m$-coumaric acid, $m$-methoxycinnamic acid, naringerin, kaempferol, caffeic acid, myricetin, gallic acid, ferulic acid, quercetin, $p$-coumaric acid, protocatechuic acid, syringic acid were all purchased from Sigma-Aldrich.

\subsection{Sample Collection}

Fifty-three honey samples [seven cambara (Gochnatia spp, Asteraceae), sixteen multifloral, thirteen orange (Citrus $\mathrm{sp}$ ) and seventeen Eucalyptus spp. (Myrtaceae)] were collected from different regions of the states of Rio de Janeiro and São Paulo, Brazil. Samples were collected from 2004 to 2010 and kept stored at $4{ }^{\circ} \mathrm{C}$ until analysis

\subsection{Sample Preparation}

The procedure for the fractionation of honey was carried out as previously described. ${ }^{20-22}$ Honey samples (50 g) were thoroughly mixed with $250 \mathrm{~mL}$ of distilled water and the solution $\mathrm{pH}$ was adjusted to 2 
with concentrated $\mathrm{HCl}$ followed by filtration through cotton wool to remove solid particles. The filtrate was mixed with $75 \mathrm{~g}$ of Amberlite XAD-2 resin, pore size $9 \mathrm{~nm}$, and particle size 0.3-1.2 mm (Supelco, Bellefonte, PA, USA) and magnetically stirred for $10 \mathrm{~min}$. The mixture was then packed into a glass column $(25 \times 2.0 \mathrm{~cm})$. The column was washed with $250 \mathrm{~mL}$ of acidified water $(\mathrm{pH} 2$ with $\mathrm{HCl}$ ) and subsequently rinsed with 300 $\mathrm{mL}$ of neutral distilled water to remove all sugars and other polar compounds in honey. The phenolic compounds were eluted from the sorbent with $500 \mathrm{~mL}$ of methanol. The methanol extracts were concentrated under

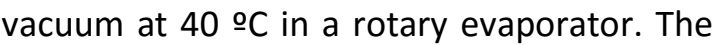
residue was dissolved in $10 \mathrm{~mL}$ of distilled water and extracted five times with $10 \mathrm{~mL}$ of ethyl acetate. The ethyl acetate extracts were combined and the solvent was removed under vacuum. The dried residue was then redissolved in $1 \mathrm{~mL}$ of methanol (HPLC grade) and filtered through a $0.45 \mu \mathrm{m}$ pore size membrane filter (Sartorius Stedim Biotech, Germany). Three replicate extractions were performed for each sample, and the standard deviation did not exceed $5 \%$. The yields of extracts were expressed as a mean of three extractions and ranged from: Citrus (10 to 32 $\mathrm{mg}$ ), Cambara (24 to $64 \mathrm{mg}$ ) and Eucalyptus (17 to $22 \mathrm{mg}$ ) per $50 \mathrm{~g}$ of honey.

\section{4. ${ }^{1} \mathrm{H}$ NMR Spectroscopy}

${ }^{1} \mathrm{H}$ NMR spectra were acquired for all 53 samples on a Bruker Avance Ultra Shield 500 spectrometer (Bruker Biospin $\mathrm{GmbH}$, Rheinstetten, Germany) operating at 500.13 $\mathrm{MHz}$ using a broadband detection $5 \mathrm{~mm}$ probe. All the spectra were obtained at 298 $\mathrm{K}$, using a $30^{\circ}$ pulse, an acquisition delay of 2 $s$ and 16 transients and a constant receiver gain. The spectra were processed using ACD/1D NMR Processor (Advanced Chemistry Development, Inc, Canada). Phasing, baseline correction and integration were done automatically by group treatment of all 53 spectra. The whole spectra from 0.00 to
$12.00 \mathrm{ppm}$ were integrated using ACD's Intelligent Bucketing, resulting in 221 integrals for each sample.

\subsection{Sample Fortification}

Fortification was performed by successive addition of $1.0 \mathrm{mg}$ of 13 pure phenolic andflavonoid standards in each honey extract previously identificated by HPLC, as shown in Figure 1. ${ }^{1} \mathrm{H} \quad \mathrm{NMR}$ spectra of the corresponding solutions were acquired, under the same conditions described above, in order to assign the corresponding signals of the standards in the different honey samples.

\subsection{Multivariate Analysis}

Principal component analysis (PCA) is an important multivariate tool for exploratory data analysis. $^{23}$ It aims at dimension reduction, i.e. using fewer variables to represent a data set. This complexity reduction is achieved through an orthogonal linear transformation of the original coordinate system so that the greatest variance by any projection of the data comes to lie on the first coordinate (called the first principal component), the second greatest variance on the second coordinate and so forth.

The new variables (loadings) are linear combinations of the original variables and have no physical meaning. However, they provide a simpler way to visualise and understand the original data set.

In NMR, in multivariate analysis studies, the variables (the $X$ matrix) are the integrals of the whole or part of the spectrum for each sample. Each sample is a point in an $n$ dimensional space of integrals. When PCA is performed, each sample can be represented in a lower dimensional space so that unseen relationships and groups can be visualized. 
<smiles>O=c1c(O)c(-c2cc(O)c(O)c(O)c2)oc2cc(O)cc(O)c12</smiles>

myricetin<smiles>O=c1cc(-c2ccc(O)cc2)oc2cc(O)cc(O)c12</smiles>

naringerin<smiles>O=c1c(O)c(-c2ccc(O)cc2)oc2cc(O)cc(O)c12</smiles>

kaempferol<smiles>O=c1c(O)c(-c2ccc(O)c(O)c2)oc2cc(O)cc(O)c12</smiles>

quercetin<smiles>COc1cc(C=CC(=O)O)ccc1O</smiles>

ferulic acid<smiles>O=C(O)/C=C/c1ccc(O)c(O)c1</smiles>

caffeic acid<smiles>O=C(O)c1ccc(O)c(O)c1</smiles>

protocatechuic acid<smiles>COc1cc(C(=O)O)cc(OC)c1O</smiles>

syringic acid<smiles>O=C(O)c1ccccc1</smiles>

benzoic acid<smiles>O=C(O)c1cc(O)c(O)c(O)c1</smiles>

gallic acid<smiles>O=C(O)/C=C/c1cccc(O)c1</smiles>

m-coumaric acid<smiles>O=C(O)C=Cc1ccc(O)cc1</smiles>

p-coumaric acid<smiles>COc1cccc(C=CC(=O)O)c1</smiles>

m-methoxycinnamic acid

Figure 1. Structures of phenolic compounds identified in honey extracts after fortification

2.7. HPLC analysis of the phenolic profile of honey

Polyphenol identification analyses were carried out using an HPLC apparatus (LC20AT, Shimadzu, Japan) equipped with a diode array detector (DAD, SPD-M20A) coupled to a LCSolution ChemStation dataprocessing station. The column used was a C18 LiChroCART $(250 \mathrm{~mm} \times 4 \mathrm{~mm}$; $5 \mu \mathrm{m}$; Merck, Darmstadt, Germany), operating at 35 ${ }^{\circ} \mathrm{C}$. The mobile phase consisted of solvent $A$ (water and acetic acid, 99:1) and solvent B (water, acetonitrile and acetic acid, 59:40:1).
The gradient program was as follows: from 25 to $100 \%$ B in $30 \mathrm{~min}$, and then isocratic by $10 \mathrm{~min}$. The injection volume was $20 \mu \mathrm{L}$, and the flow rate was $1 \mathrm{~mL} \mathrm{~min}^{-1}$. Chromatograms for the phenolic acids were monitored at $270 \mathrm{~nm}$ and for flavonoids at $360 \mathrm{~nm}$. The identification of phenolic compounds was based on a comparison of chromatographic data (retention times and UV spectra) with authentic markers. 


\section{Results and discussion}

The ${ }^{1} \mathrm{H}$ NMR spectra of the honey extracts exhibited characteristic signals for phenolic compounds, as shown in Figure 2 (fortification), which were confirmed by
HPLC-DAD (Figure 3). Due to the overlapping of signals, their attribution in the NMR spectra was only possible for major phenolic compounds after fortification. The detailed attribution of the phenolic reference compounds (Figure 1) is summarized in Table 1.
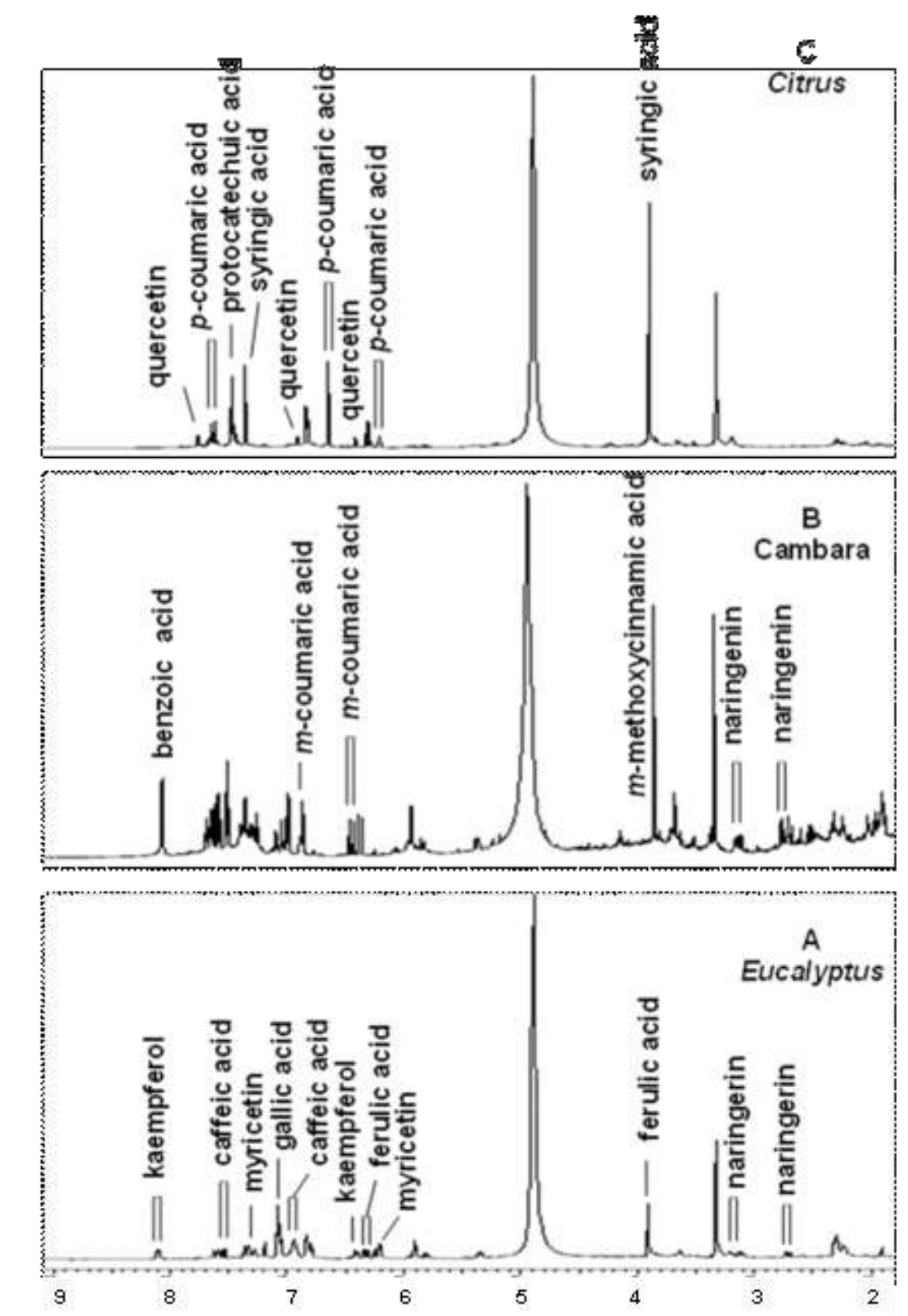

Figure 2. Representative $500 \mathrm{MHz}{ }^{1} \mathrm{H}$ NMR spectra ( $\delta$ 2.0-9.0) of (A) Eucaliptus, (B) Cambara and $(\mathrm{O})$ Orange honey extracts along with the assignment of resonances following spiking of 13 standard polyphenols. (For resolution reasons the spectra presented were processed using Gaussian multiplication of the FID ( $L B=-2, G B=0.1$ prior to Fourier transform) 


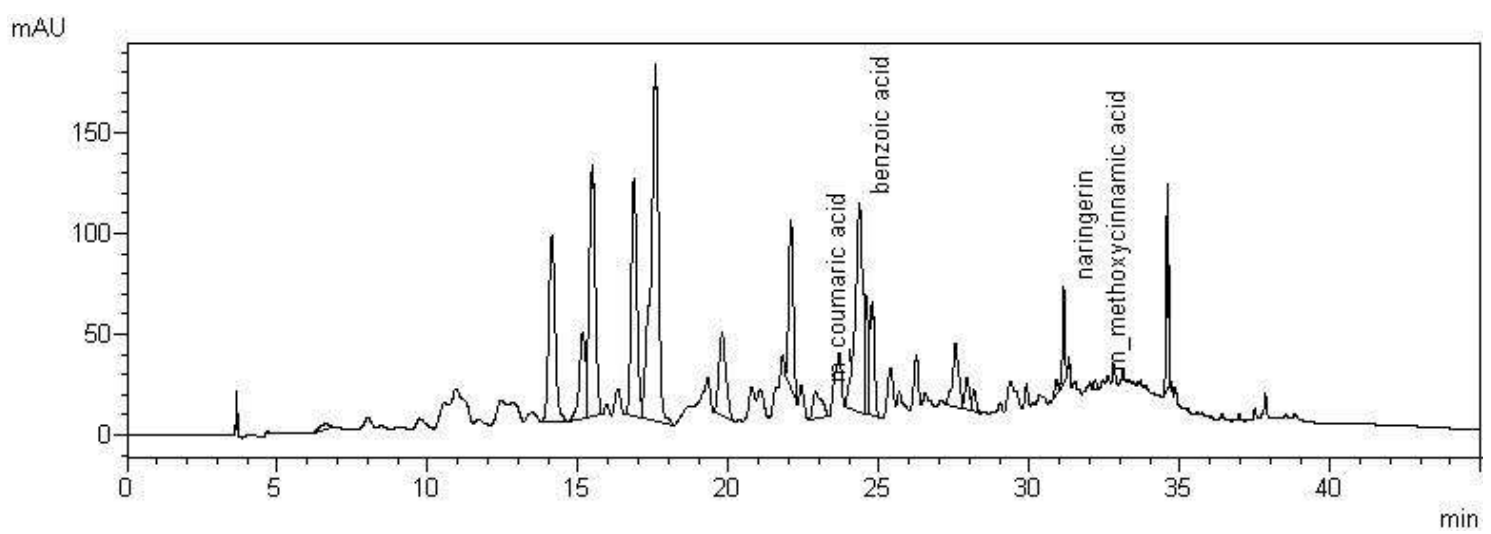

Figure 3. Chromatogram of the honey extract of Cambara at $\lambda=280 \mathrm{~nm}$

Table 1. ${ }^{1} \mathrm{H}$ NMR chemical shifts of phenolic components detected in honey

\begin{tabular}{lll}
\hline $\mathrm{N}^{\circ}$ & Compound & $\delta 1 \mathrm{H}$ (multiplicity, assignment) \\
\hline 1 & benzoic acid & $8.04(\mathrm{dd}, \mathrm{H} 1, \mathrm{H} 6)$ \\
2 & m-coumaric acid & $6.41(\mathrm{dd}, \mathrm{H}-\beta), 7.86(\mathrm{dd}, \mathrm{H}-\alpha)$ \\
3 & m-methoxycinnamic acid & $3.84(\mathrm{~s}, \mathrm{OMe} 3)$ \\
4 & naringerin & $2.7(\mathrm{dd}, \mathrm{H} 3), 3.09(\mathrm{dd}, \mathrm{H} 3)$ \\
5 & kaempferol & $8.08\left(\mathrm{~d}, \mathrm{H} 2^{\prime}, \mathrm{H} 6^{\prime}\right), 6.41(\mathrm{~d}, \mathrm{H} 8)$ \\
6 & caffeic acid & $7.53(\mathrm{~d}, \mathrm{H}-\alpha), 6.93(\mathrm{dd}, \mathrm{H} 6)$ \\
7 & myricetin & $7.28\left(\mathrm{~s}, \mathrm{H}-2^{\prime}\right), 6.21(\mathrm{~d}, \mathrm{H}-6)$ \\
8 & gallic acid & $7.08(\mathrm{~s}, \mathrm{H} 2, \mathrm{H} 6)$ \\
9 & ferulic acid & $6.47(\mathrm{~d}, \mathrm{H}-\beta), 3.90(\mathrm{~s}, \mathrm{OMe} 5)$ \\
10 & quercetin & $6.89\left(\mathrm{~d}, \mathrm{H} 5^{\prime}\right), 6.40(\mathrm{~d}, \mathrm{H} 8), 6.19(\mathrm{~d}, \mathrm{H} 6)$ \\
11 & p-coumaric acid & $7.60(\mathrm{~d}, \mathrm{H}-\alpha), 6.28(\mathrm{~d}, \mathrm{H}-\beta), 6.80(\mathrm{~d}, \mathrm{H} 3, \mathrm{H} 5)$ \\
12 & protocatechuic acid & $7.46(\mathrm{dd}, \mathrm{H} 1, \mathrm{H} 6)$ \\
13 & syringic acid & $7.32(\mathrm{~s}, \mathrm{H} 2, \mathrm{H} 6), 3.87(\mathrm{~s}, \mathrm{OMe3}, \mathrm{OMe} 5)$ \\
\hline
\end{tabular}

$s$, singlet; $d$, doublet; dd, doublet of doublet

The ${ }^{1} \mathrm{H}$ NMR spectra were segmented, integrated and normalized, and the data were sub-projected to PCA. Two PCA's were performed, one using multifloral and orange honey samples (Figure 4 ) and the other using cambara, orange and eucalyptus monofloral honey samples (Figure 5). Both analyses afforded a very clear discrimination among the honey floral origins, thus becoming a good alternative to melissopalynology. 


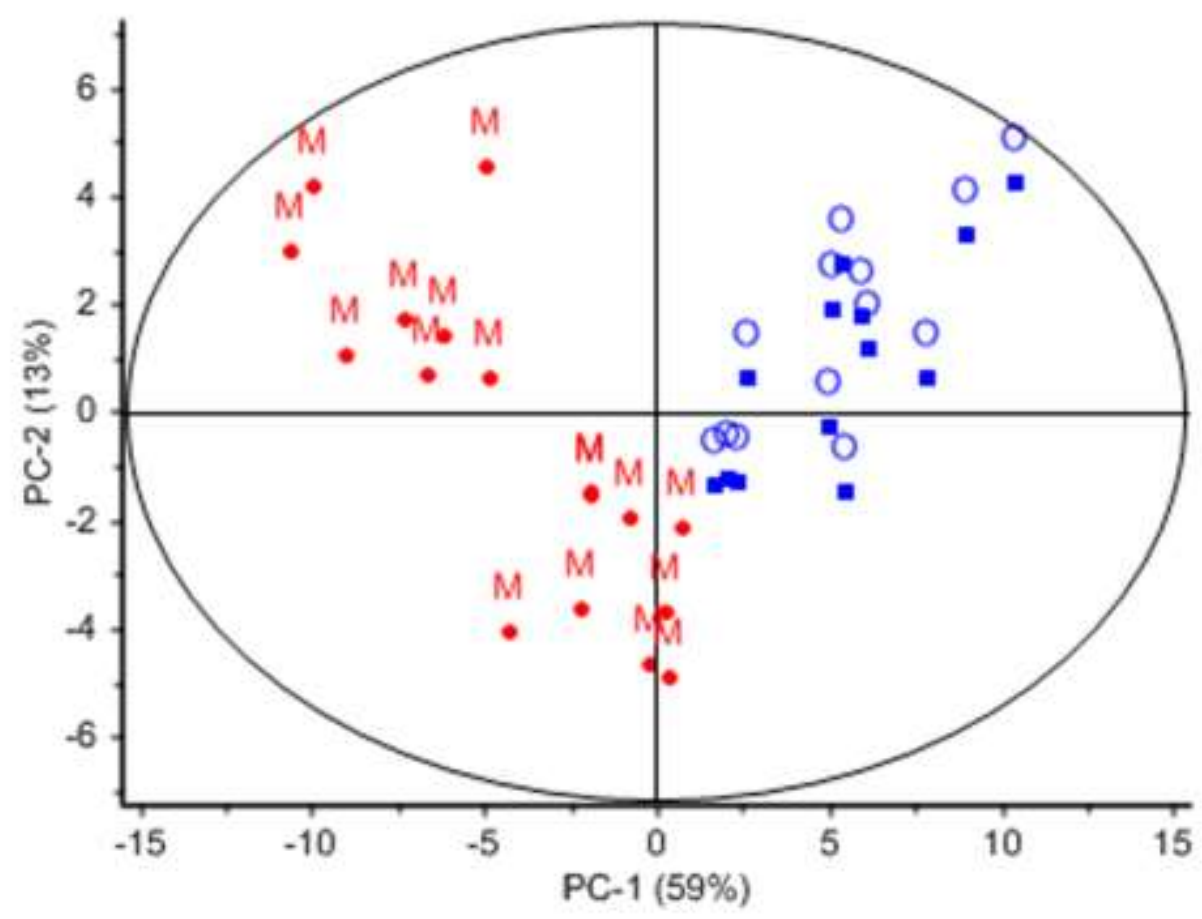

Figure 4. PCA scores plots derived from ${ }^{1} \mathrm{H}$ NMR spectra of orange and multifloral honey extracts: (O) Orange and (M) Multifloral

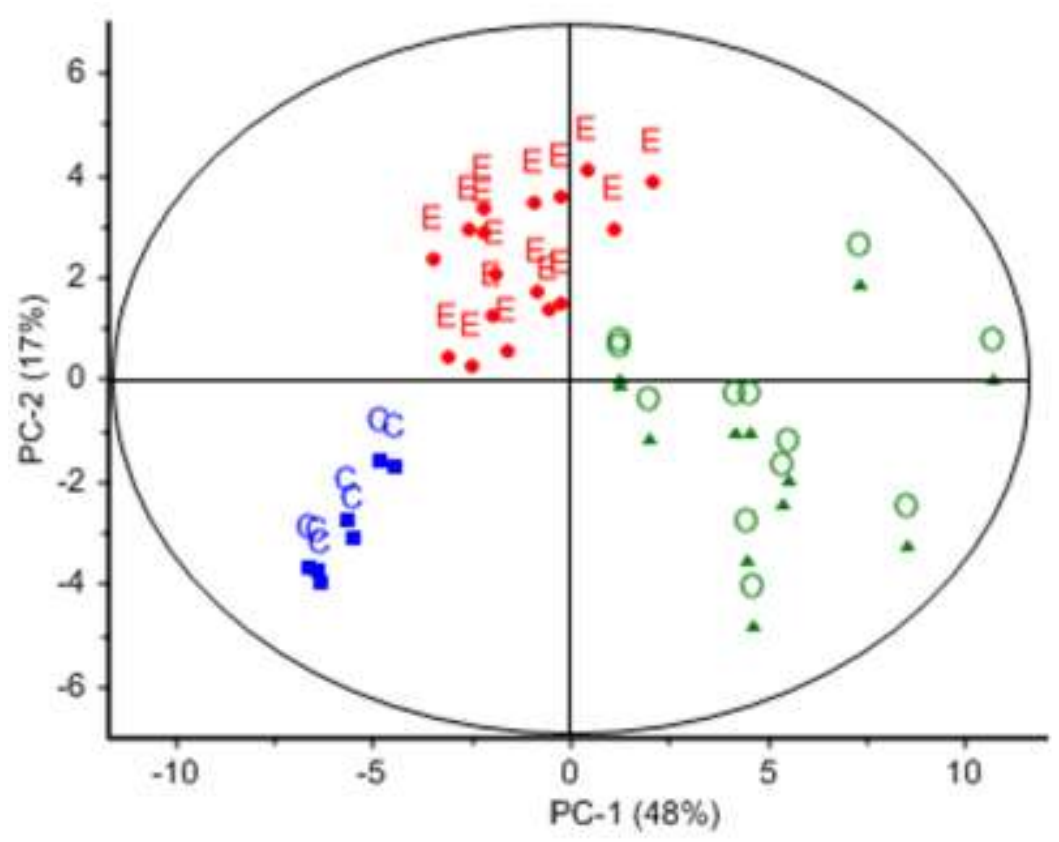

Figure 5. PCA scores plots derived from ${ }^{1} H$ NMR spectra of orange (O), cambara (C) and eucalyptus (E) honey extracts

Biomarkers characteristic of some flora have been described in the literature, being responsible for the clear discrimination observed in the PCA. ${ }^{24}$ Some of these 
biomarkers were found in a great part of the samples studied in this work. Figure 2 (fortification) shows the major phenolic compounds found in each floral origin, which were used in the fortification in order to make it possible to identify them in the samples, due to their low concentration in the honey extracts.

Many studies have been carried out to seek for alternatives to sensorial and melissopalynological honey typification. ${ }^{25}$ Among them, ${ }^{1} \mathrm{H}$ NMR associated to chemometrics has been highlighted. There is a huge diversity in honey constituents, which depends intimately on its botanical origin, though seasonal and environmental factors may also interfere on its composition, including its phenolic profile. Many authors have suggested the possible correlations between floral origin and honey's phenolic profile. ${ }^{26}$ Therefore, flavonoids, phenolic acids, aminoacids and some aromatic and heterocyclic aldehydes are being evaluated in order to help distinguish honey floral origin.

The presence of some individual components or group of compounds is being evaluated as possible biomarkers that may be used in honey typification. The flavonoids myricetin, tricetin, luteolin, quercetin, and kaempferol have been suggested as floral markers for Eucalyptus honeys, as well as gallic acid and some other benzoic acid derivatives ${ }^{27}$, while hesperitin, quercetin, crisin, caffeic acid, $p$-coumaric acid and ferulic acid have been described as possible Citrus honey markers. ${ }^{27}$

\section{Conclusions}

In this study, phenolic compounds such as miricetin, kaempferol and gallic acid were identified in Eucalyptus honey samples, as well as naringenin, caffeic and ferulic acids. Quercetin and $p$-coumaric acid could also be identified in citrus samples, which have already been described as possible markers ${ }^{27}$, as well as syringic and protocatechuic acids. Finally, $p$-methoxycinnamic acid and $m$ - coumaric acid were identified in all the Cambara honey samples, as well as naringenin and benzoic acid. Principal component analysis was successfully applied for the discrimination among eucalyptus, orange and cambara honey samples. Finally, the association of PCA and NMR techniques might be an important tool to evaluate honeys with poor pollen content and even with excess pollen content, which can mask the nectar predominance of other species and interfere on the melissopalinological analysis.

\section{References}

${ }^{1}$ Gheldof, N.; Wang, X. H.; Engeseth, N. H. Identification and quantification of antioxidant components of honeys from various floral sources. Journal of Agricultural and Food Chemistry 2002, 50, 58. [CrossRef] [PubMed]

${ }^{2}$ White, J. W.; Composition of honey. Honey. A comprehensive survey, Crane, Russak \& Company: London, 1975.

${ }^{3}$ Khalil, M. I.; Sulaiman, S. A.; Boukraa, L. Antioxidant properties of honey and its role in preventing health disorder. The Open Nutraceuticals Journal 2010, 3, 6. [CrossRef]

${ }^{4}$ Winston, M. L. The Biology of the Honey Bee. Harvard University Press: Massachusetts, 1987.

${ }^{5}$ Al-Mamarya, M.; Al-Meeri, A.; Al-Habori, M. Antioxidant activities and total phenolics of different types of honey. Nutrition Research 2002, 22, 1041. [CrossRef]

${ }^{6}$ Ouchemoukh, S.; Louaileche, H.; Schweitzer, P. Physicochemical characteristics and pollen spectrum of some Algerian honeys. Food Control 2007, 18, 52. [CrossRef]

${ }^{7}$ Baroni, M. V.; Chiabrando, G. A.; Costa, C.; Wunderlin, D. A. Assessment of the floral origin of honey by SDS-page immunoblot techniques. Journal of Agricultural and Food Chemistry 2002, 50, 1362. [CrossRef] [PubMed]

${ }^{8}$ Consonni, R.; Cagliani, L. R. Geographical characterization of polyfloral and Acacia 
honeys by Nuclear Magnetic Resonance and chemometrics. Journal of Agricultural and Food Chemistry 2008, 56, 6873. [CrossRef] [PubMed]

${ }^{9}$ Schievano, E.; Stocchero, M.; Morelato, E.; Facchin, C.; Mammi, S. An NMR-based metabolomic approach to identify the botanical origin of honey. Metabolomics 2012, 8, 679. [CrossRef]

${ }^{10}$ Boffo, E.; Tavares, L.; Tobias, A.; Ferreira, M.; Ferreira, A. Identification of components of Brazilian honey by $1 \mathrm{H}$ NMR and classification of its botanical origin by chemometric methods LWT - Food Science and Technology 2012, 49, 55. [CrossRef]

${ }^{11}$ Cavazza, A.; Corradini, C.; Musci, M.; Salvadeo, P. High-performance liquid chromatographic phenolic compound fingerprint for authenticity assessment of honey. Journal of the Science of Food and Agriculture 2013, 93, 1169. [CrossRef] [PubMed]

${ }^{12}$ Ferreres, F.; Ortiz, A.; García-Viguera, C.; Tomas-Barberan, F. A.; Tomas-Lorente, F. Flavonoids of la alcarria-honey - A study of their botanical origin Zeitschrift für Lebensmittel-Untersuchung und Forschung 1992, 194, 2, 139. [CrossRef]

${ }^{13}$ Zhou, J.; Yao, L.; Li, Y.; Chen, L.; Wu, L.; Zhao, J. Floral classification of honey using liquid chromatography-diode array detectiontandem mass spectrometry and chemometric analysis. Food Chemistry 2014, 145, 941. [CrossRef] [PubMed]

${ }^{14}$ Ferreres, F.; García-Viguera. C.; TomásLorente, F.; Tomás-Barberan, F. A. Hesperetin: a marker of the floral origin of citrus honey. Journal of the Science of Food and Agriculture 1993, 61, 1,121. [CrossRef]

${ }^{15}$ Hermosın, I.; Chicon, R.; Cabezudo, M. D. Free amino acid composition and botanical origin of honey. Food Chemistry 2003, 83, 263. [CrossRef]

${ }^{16}$ Bonaga, G. and Giumanini, A. G. The volatile fraction of chestnut honey. Journal of Apicultural Research 1986, 25, 113. [CrossRef]

${ }^{17}$ D'arcy, B. R.; Rintoul G. B.; Rowland C. Y.; Blackman, A. J. Composition of Australian honey extractives. 1. Norisoprenoids,
Monoterpenes, and other natural volatiles from Blue Gum (Eucalyptus leucoxylon) and Yellow Box (Eucalyptus melliodora) honeys. Journal of Agricultural and Food Chemistry 1997, 45, 5, 1834. [CrossRef]

18 Joerg, E.; Sontag, G. Multichannel coulometric detection coupled with liquid chromatography for determination of phenolic esters in honey. Journal of Chromatography A 1993, 635, 137. [CrossRef] [PubMed]

${ }^{19}$ Tan, S. T., Wilkins, A. L., Holland, P. T. and McGhie, T. K. J. Extractives from New Zealand honeys. 2. Degraded carotenoids and other substances from heather honey. Journal of Agricultural and Food Chemistry 1989 37, 1217. [CrossRef]

${ }^{20}$ Pyrzynska, K.; Biesaga, M. Analysis of phenolic acids and flavonoids in honey. TrAC Trends in Analytical Chemistry 2009, 28, 893. [CrossRef]

${ }^{21}$ Ferreira, I. C. F. R.; Aires, E.; Barreira, J. C. M.; Estevinho, L. M. Antioxidant activity of Portuguese honey samples: Different contributions of the entire honey and phenolic extract. Food Chemistry 2009, 114, 1438. [CrossRef]

${ }^{22}$ Meda, A.; Lamien, C. E.; Romito, M.; Millogo, J.; Nacoulma, O. G. Determination of the total phenolic, flavonoid and proline contents in Burkina Fasan honey, as well as their radical scavenging activity. Food Chemistry 2005, 91, 571. [CrossRef]

${ }^{23}$ Jackson, J.E. User's Guide to Principal Components. Wiley and Sons: New York, 1991. [CrossRef]

${ }^{24}$ Schievano, E.; Stocchero, M.; Morelato, E.; Facchin, C.; Mammi, S An NMR-based metabolomic approach to identify the botanical origin of honey. Metabolomics 2011, 7, 1. [CrossRef]

${ }^{25}$ Bertoncelj, J.; Golob, T.; Kropf, U.; Korosec, M. Characterisation of Slovenian honeys on the basis of sensory and physicochemical analysis with a chemometric approach. International Journal of Food Science \& Technology 2011, 46, 1661. [CrossRef]

${ }^{26}$ Lachman, J.; Hejtmánková, A.; Sýkora, J.; Karban, J.; Orsák, M.; Rygerová, B. Contents 
of Major Phenolic and Flavonoid Antioxidants in selected Czech honey. Czech Journal of Food Sciences 2010, 28, 412. [Link]
${ }^{27}$ Kaškonienė, V.; Venskutonis, P. R. Floral markers in honey of various botanical and geographic origins: A Review. Comprehensive Reviews in Food Science and Food Safety 2010, 9, 620. [CrossRef] 